\title{
An obligation to remedy damage in connection with an early release on licence
}

\author{
ANNA MuSZYŃSKA \\ Departament of Substantive Criminal Law \\ Faculty of Law, Administration and Economics \\ University of Wroclaw, Poland
}

Up to the present time, in the system of measures to combat crime, compensation for damage caused by an offence has been provided for in all criminal codifications. The idea of compensation has been developed in these codifications, i.a. through additional penalties, probationary measures, penal measures or finally compensatory measures - an obligation to remedy damage. Typical of the said codifications was the multiplicity of grounds. The consequence was that the criminal-law obligation to remedy damage has been imposed by the courts in connection with the measures relating to placing an offender on probation or on an independent legal basis of criminal justice response measures. Their determinants, character or effects of execution varied, which destabilised the situation of the aggrieved party, who expected due compensation being unable to comprehend those normative complexities.

Among numerous legal grounds for an obligation to remedy damage, one such power was also vested by the legislator in the penitentiary court, when the said court adjudicates on release on licence of an offender sentenced to imprisonment from serving the balance of the sentence. There 
is no extensive literature on the subject and the analyses usually focus on the most frequently-applied in practice grounds for imposing an obligation to remedy damage. It is therefore extremely useful to take a closer look at this issue in more detail, paying due attention to the legitimacy of such a regulation and the role it plays in case law.

Recalling the first solutions in this regard, it is crucial to indicate that already in the Criminal Code of 1932 an obligation to remedy damage had been provided within the framework of broadly understood probation. In the 1932 Criminal Code an obligation to remedy damage was designed as a probationary measure applicable in connection with a conditional suspension of the sentence. At the time, an obligation to remedy damage could not have been imposed in connection with an early release on licence. Pursuant to art. $62 \S 2$ of the 1932 Criminal Code, as far as economic relations of the convict allowed, the court could impose on him an obligation to remedy damage caused by an offence within the limits and time framework laid down in the judgement. In the event that the convict failed to fulfil the obligation to remedy damage imposed on him, the condition to optionally order the execution of a conditionally suspended sentence was met.

The code did not specify whether the damage had to be solely material or also moral in nature. The manner of damage compensation, as well its conditions, time limit and extent, were left to the discretion of the judge. A court decision imposing an obligation to remedy damage did not constitute an enforcement order and did not preclude the aggrieved party from making property claims arising from an offence in civil proceedings. It has been stressed that such a decision is autonomous and independent of civil action. Furthermore, it was emphasised that an obligation to remedy damage has an independent substantive legal basis and the rules of civil law, in particular the code of obligations, may be applied in such instances only in an ancillary manner, by analogy.

In an explanatory statement to the 1932 Criminal Code, it has been expressly indicated that

an obligation to remedy damage constitutes neither an award in civil action nor exemplary damages, but it is an independent institution allowing the judge to impose on the convict an obligation to redress the damage within the limits which the judge finds equitable (or otherwise the suspended sentence shall be executed); [...] this institution has no bearing 
on the civil law rights of the aggrieved party, it does not, as such, settle civil claims, but is solely an institution of criminal policy, relating to the person of the convict and not to civil claims of the aggrieved party; [...] the judge is not bound to make his decision dependent neither on the existence of civil action or its extent, nor on the demand or consent of the aggrieved party, but he must solely take into account the criminal-policy interests. ${ }^{1}$

Remedying damage as a penal-law measure served specified criminal policy goals, although it did not preclude the aggrieved party from pursuing property claims arising from an offence.

The courts however, applying the institution of suspended sentence rarely imposed the obligation to remedy damage on the convict. Nevertheless, in literature emphasis was placed on the significance of this measure. ${ }^{2}$ The Supreme Court in its guidelines dated 16 October 1957 also underlined that:

When applying conditionally suspended execution of a sentence, the courts should $[\ldots]$ consider whether imposing on the convict an obligation to fully or partially remedy damage caused by the committed offence will be effective. For the provision of art. 62 $\S 2$ of the Criminal Code, which in practice has almost completely fallen out of use, is an effective measure of rational criminal policy $[\ldots] .^{3}$

An analysis of criminal cases and data from court statistics demonstrated that such an obligation was imposed primarily on offenders with a suspended sentence, who were convicted for offences against life and health, persistent evasion of the duty of alimony, violent attacks against personal and individual property, as well as in cases concerning causing penalised deficits or mismanagement. ${ }^{4}$

In the search for causes of infrequent application of an obligation to remedy damage in practice, the following have been indicated: lack of appreciation of criminal and political character of the said institution, not entirely clear (from the point of view of legal practice) relation between an obligation to remedy damage and the civil law regulations, in par-

${ }^{1}$ Codification Committee. Criminal Law Division, vol. V, is. 6, p. 15 et seq.; unless stated otherwise - own translation.

${ }^{2}$ See J. Śliwowski, "Filozoficzno-prawne znaczenie art. 62 polskiego kodeksu karnego", Palestra 1934, no. 7, p. 224 et seq.

${ }^{3}$ Supreme Court Decision of 1958, no. 1, as cited in M. Leonieni, "Naprawienie szkody przy warunkowym zawieszeniu wykonania kary na tle nowej kodyfikacji karnej", Palestra 1970, no. 5, p. 54.

${ }^{4}$ M. Leonieni, op. cit., p. 54. 
ticular those on civil action. Moreover, it has been stressed that judicial authorities were reluctant to take additional actions regarding supervision over the enforcement of conditions set forth in art. $62 \S 2$ of the Criminal Code. $^{5}$

An obligation to remedy damage was regulated in the 1944 Criminal Code of the Polish Army ${ }^{6}$ differently than in the 1932 Criminal Code. In the 1944 Code, drawing on the example of Soviet legislation, the said obligation was regulated as an additional penalty, subject to court and administrative enforcement. This penalty was abolished by the amendment of 31 January $1961 .^{7}$

As a penalty, an obligation to remedy damage was also provided for in the draft Criminal Code of 1951, where in art. 81 it was stated that: "the court imposes an obligation to remedy damage in cases specified by law, if imposing another penalty would be ineffective." However, the proposed version was not adopted and the concept of an obligation to remedy damage as a penalty was subsequently rejected.

A different approach to an obligation to remedy damage was taken in the 1959 Act on Criminal Liability for Offences against Social Capital. ${ }^{8}$ In article 8 therein it was laid down that in cases concerning offences specified in this Act, the application of the institution of conditionally suspended execution of sentence was dependent upon the prior full redress of the damage caused by the offence.

In the 1969 Criminal Code the scope of application of an obligation to remedy damage was substantially broadened. This measure was provided for not only when imposing conditional suspension of sentence

5 M. Leonieni, "Wynagrodzenie wyrządzonej szkody a warunkowe skazanie", Nowe Prawo (further as NP) 1958, no. 12, pp. 30-31; idem, "Wynagrodzenie szkody przy warunkowym zawieszeniu wykonania kary", NP 1963, no. 7-8, pp. 764-765.

${ }^{6}$ Criminal Code of the Polish Army - Decree of the Polish Committee of National Liberation (PKWN) of 23 September 1994, Dz.U. (Journal of Laws) No. 6, item 27, as amended.

7 Dz.U. (Journal of Laws) of 1961 No. 6, item 40.

8 Dz.U. (Journal of Laws) No. 36, item 228 as amended; the said statute was repealed by the Act on Provisions Implementing the Criminal Code of 19 April 1969, Dz.U. (Journal of Laws) No. 13, item 95, as of 1 January 1970. 
(art. $75 \S 2$ and $\S 3$ of the Criminal Code), but also in connection with conditional discontinuance of criminal proceedings (art. $28 \S 2$ and of the Criminal Code), restriction of liberty (art. 35 and art. $294 \S 4$ (2) of the Criminal Code) and early release on licence (art. 94 of the Criminal Code). In the event of conditional discontinuation of proceedings for offences against social property (art. $28 \S 3$ of the Criminal Code) and conditional suspension of the execution of a sentence imposed for seizure of social property (art. $75 \S 3$ of the Criminal Code) imposition of an obligation to remedy damage was mandatory.

The criminal statute of 1969 provided for new possibilities to apply criminal-law obligation to remedy damage as a probationary measure. Particular emphasis was placed on the protection of social property. A fundamental change however, concerned making the judicial decision imposing an obligation to remedy damage issued pursuant to the 1969 Criminal Code similar to the judicial decision awarding damages pursuant to civil law provisions by acknowledging in art. $94 \S 2$ of the Code of Criminal Procedure of 1969 that: "an obligation to remedy damage imposed by the court in connection with the execution of a conditionally suspended sentence is also deemed to be a decision on property claims". Such a decision, in the circumstances specified in the provision, served as an enforcement order, which gave rise to doubts concerning its relation to civil claims, which included claims pursued in ancillary proceedings, recognised ex officio or pursued in civil proceedings.

The measures adopted in the 1969 Criminal Code allowed the damage caused by the offence to be remedied to a greater extent. However, differences in these measures and varying effects of their practical application provoked debates, in particular with regard to an obligation to remedy damage imposed in connection with conditional suspension of the execution of a sentence. The discrepancies between the decisions of criminal and civil courts with regard to setting the amount of compensation, criminal-law issues of remedying damage and consequences in the area of civil law generated controversies, but at the same time were of real practical significance. Disputes concerning the legal status of the obligation under art. $75 \S 2$ (1) of the Criminal Code have also arisen. Different stances were taken, those in accordance with which the obligation 
was of a criminal-law character ${ }^{9}$ were confronted with the ones assuming its mixed character, connected both with civil as well as criminal law. ${ }^{10}$

Interpretation difficulties were supposed to be eliminated by the criminal codification of 1997, which retained the possibility to impose an obligation to remedy damage in connection with conditional discontinuance of criminal proceedings (art. $67 \S 3$ of the Criminal Code) and conditional suspension of the execution of a sentence (art. $72 \S 2$ of the Criminal Code), but at the same time removed the possibility to impose an obligation to remedy damage in connection with early release on licence. Criminal codification of 1997 introduced certain novel solutions to the substantive provisions, including an obligation to remedy damage not only in the category of probationary measure, but also formulating it as an independent penal measure (art. 46 of the Criminal Code). As of the amendment, which came into force on 1 July 2015, the obligation to remedy damage imposed as penal measure became a compensatory measure. ${ }^{11}$

Presented above is a brief description of the grounds for imposition of an obligation to remedy damage (excluding additional institutions with historical relevance only, such as: ancillary proceedings and ex officio compensation) which demonstrates that the legislator develops compensatory instruments, however it seems that an optimal model has not been reached so far. This would require an in-depth examination of solutions applicable to compensatory measures and elimination of other legal grounds for imposition of an obligation to remedy damage.

Focusing attention on one of the such grounds, namely the possibility to impose an obligation to remedy damage in connection with early release on licence, it should be noted that this legal basis did not play any substantial role; at best it was a supplementary, yet still marginal, role.

9 See W. Daszkiewicz, Naprawienie szkody w prawie karnym, Warszawa 1972, p. 15 et seq.; Z. Gostyński, "Zobowiązanie skazanego do naprawienia szkody jako orzeczenie co do roszczeń majątkowych", Palestra 1971, no. 5, p. 54 et seq.

10 A. Murzynowski, "Nałożenie obowiązku naprawienia skutków przestępstwa jako element nowej polityki karania", Państwo i Prawo (further as PiP) 1970, no. 5, p. 713 et seq.

11 An amendment to article 46 of the Criminal Code, introduced by the Act on Amendment of the Criminal Code and on Amendments to Certain Other Acts of 20 February 2015 (Dz.U. [Journal of Laws] of 2015, item 396), which came into force on $1^{\text {st }}$ July 2015. 
As showed previously, the possibility to release on licence an offender sentenced to imprisonment from serving the balance of the sentence was the third institution related to the period of probation, with which an obligation to remedy damage was linked in the 1969 Criminal Code. Early release on licence was applied if there was reasonable cause to believe that the sentence imposed was effective even before the expiry of the time limit set forth in the judgement. ${ }^{12}$ Pursuant to art. 94 of the 1969 Criminal Code, the court was applying accordingly, in connection with early release on licence, art. $75 \S 2$ and 3 of the Criminal Code regulating the possibility to impose on the convict obligations during the period of probation, including the obligation to remedy damage. Reference to art. $75 \S 2$ and 3 of the Criminal Code caused that the obligation to remedy damage was shaped in accordance with the rules applicable to this probationary measure imposed in connection with a conditionally suspended sentence. In the event of conviction for an offence of seizure of social property the court was obliged to impose an obligation to remedy damage.

A penitentiary court imposed an obligation to remedy damage in the event of early release on licence at a sitting by way of an order (art. $78 \S 1$ of the Criminal Enforcement Code). Under art. $79 \S 3$ of the 1969 Criminal Code, the convict could not lodge a complaint against that order. The right to file a complaint against an order on early release on licence was vested only in the public prosecutor. The convict was entitled to lodge a

12 See more on early release on licence f. ex. J. Lachowski, "Warunkowe przedterminowe zwolnienie w prawie polskim na tle ustawodawstwa państw Rady Europy", [in:] X lat obowiazywania Kodeksu karnego wykonawczego, ed. S. Lelental, G.B. Szczygieł, Białystok 2009, p. 211; idem, "Instytucja warunkowego przedterminowego zwolnienia", PiP 2008, no. 2, p. 110; idem, "Przesłanka materialna warunkowego przedterminowego zwolnienia na gruncie kodeksu karnego", Prokuratura i Prawo 2008, no. 11, p. 36; S. Lelental, "Warunkowe przedterminowe zwolnienie w orzecznictwie Sądu Najwyższego i sądów apelacyjnych w latach 2000-II półrocze 2002 r.”, Przegląd Więziennictwa Polskiego (further as PWP) 2003, no. 40-41 p. 192; idem, "Warunkowe przedterminowe zwolnienie w orzecznictwie Sądu Najwyższego i sądów apelacyjnych w latach 2003-2004", PWP 2005, no. 49, p. 25; idem, "Warunkowe przedterminowe zwolnienie w orzecznictwie Sądu Najwyższego i sądów apelacyjnych w 2005 roku”, PWP 2006, no. 50, p. 135; B. Stańdo-Kawecka, "Warunkowe przedterminowe zwolnienie w krajach europejskich", PWP 2007, no. 54, p. 57. 
complaint against an order refusing the granting of early release on licence. This solution was especially criticised, because the 1969 Criminal Code in instances when an obligation to remedy damage was imposed provided the convict with an opportunity to be heard by the court, however it did not provide for an opportunity to challenge the court's decision in this regard.

The fulfilment of the obligation to remedy damage was subject to verification during the probation period. In the event the convict failed to fulfil the obligation, it was necessary to determine whether he had a chance or made reasonable efforts to fulfil it. Only upon confirmation that the convict did not fulfil the obligation even though he had an opportunity to do so, the court could consider revoking early release on licence. Thus, such a revocation did not occur automatically, but only after examination of the circumstances and after the convict was heard.

Imposing an obligation to remedy damage in connection with early release on licence required also a reference to concurrence of grounds for compensation, nevertheless such a problem was easier to solve, because at the stage at which the court decision was issued it was already known whether the court in the first and second instance decided on the issue of remedying damage. Moreover, criminal-law doctrine indicated that if it is admissible to impose an obligation to remedy damage in connection with a conditional suspension of the execution of a sentence despite the existence of a prior, final, and non-appealable court decision on property claims, then it is all the more admissible in connection with early release on licence. Such an opinion was connected with a quite distinct separation of criminal-law and civil-law obligation to remedy damage. A similar position was adopted by the Supreme Court in its resolution of 14th June 1974, where the court stated:

In the event of early release on licence of an offender sentenced to imprisonment for seizure of social property, the penitentiary court imposes on the convict - if the damage has not been remedied so far - an obligation to remedy damage irrespective of whether the court in the judgement imposed on the convict duty to pay damages (art. $363 \S 1$ of the Code of Criminal Procedure) or awarded civil action. ${ }^{13}$

13 VI KZP 10/74, no. 9, item 159. 
The position of the court concerned a situation, in which at the time of deciding on early release on licence, the damage has not been remedied yet in connection with the previous award in civil action or ex officio damages.

An analysis of the percentage of decisions concerning an obligation to remedy damage in relation to the number of convicts released on licence in the years 1976-1980, carried out by Z. Gostyński, revealed that the number of decisions imposing an obligation to remedy damage in connection with early release on licence amounted to $4 \%$ of all releases. ${ }^{14}$ In 1981 the application rate of the obligation to remedy damage in connection with release on licence fell significantly. ${ }^{15}$ According to Z. Gostyński, in the later period, between 1991 and 1995, a clear downward trend could be observed in the rate of impositions of an obligation to remedy damage in connection with release on licence. ${ }^{16}$ The author states that between 1976 and 1995 the application rate of the obligation to remedy damage in connection with release on licence fell 20 -fold. Z. Gostyński cautiously evaluates the interpretation of statistical data, having due regard to the variety of factors that influence such data, including particular conditions of imposition of an obligation to remedy damage in connection with early release on licence at this stage.

It is possible that the statistical data impacted the decision in accordance with which, contrary to the 1969 Criminal Code, an obligation to remedy damage was not linked with the institution of conditional release on licence in criminal codification of 1997. In art. 159 of the 1997 Criminal Enforcement Code regulating the obligations, which a penitentiary court may impose on a person conditionally released, art. $72 \S 2$ of the Criminal Code was left out, and only a reference to art. $72 \S 1$ of the Criminal Code was made. Thus, the legal basis existing up to then

14 Z. Gostyński, Obowiązek naprawienia szkody w nowym ustawodawstwie karnym, Zakamycze 1999, pp. 23-24.

15 Z. Gostyński, Karnoprawny obowiązek naprawienia szkody, Katowice 1984, p. 60.

16 Z. Gostyński, Obowiazek naprawienia szkody..., p. 23. The author indicates the following data: the period of 1976-1980: 1976 - 4.44 (percentage of an obligation to remedy damage in relation to the number of conditionally released), $1977-4.33,1978$ - 3.80, $1979-4.21,1980-4.67,1981-2.76$; the period of 1991-1995: $1991-$ $0.55,1992-0.45,1993-0.26,1994-0.34,1995-0.23$. 
was eliminated. In the explanatory statement to the Criminal Enforcement Code no remarks were made with regard to the said change. It can be only inferred, that lack of practical application of this institution resulted in such a normative decision.

The legislator however did not remain consistent and with an amendment made in 2012 once again introduced, in art. $159 \S 1$ of 1997 Criminal Enforcement Code, the legal basis for an imposition of an obligation to remedy damage in connection with early release on licence. ${ }^{17}$ Pursuant to the above-mentioned provision, if the harm caused by an offence for which the offender was convicted has not been remedied, the penitentiary court may impose an obligation stipulated in art. $72 \S 2$ of the Criminal Code. The decision in that regard is made by the penitentiary court at a sitting by way of an order, which is appealable (art. $162 \S 2$ of the Criminal Enforcement Code).

To return to the indicated legal basis, in the first place it should be considered whether it is justified. It can be presumed that the legislator, following broadly understood protection of interests of the aggrieved party, introduced one additional legal basis safeguarding the aggrieved party in the event, when the convict at the stage of execution of the sentence has not yet remedied the damage, and wanted to benefit from an early release on licence. The sole intent of the legislator may seem worthy of support, with the exception of an amended concept of compensatory measure and civil-law consequences of imposition of the obligation to remedy damage. One of the issues that first comes to mind is the problem of concurrence of legal grounds for imposition of an obligation to remedy damage as a probationary condition, compensatory measure, or finally, a decision on compensation in the area of civil law. Under the current criminal codification in force, in order to avoid granting more than one enforcement order with regard to remedying damage, provisions prohibiting aggregation ("anticumulative") are made. Moreover, criminal-law imposition of the obligation to remedy damage in terms of its executive effects is treated as a decision concerning property claims specified in civil law. The approach with regard to this issue has changed considerably when

17 An Act on Amendments to the Criminal Enforcement Code and Amendments to Certain Other Acts of 16 September 2011, Dz.U. (Journal of Laws) No. 240, item 1431, which came into effect on 1st of January 2012. 
compared to the positions adopted in previous criminal codifications of 1931 or 1969 . Therefore, it is hard to imagine a situation illustrated by the following example: first, a trial court upon hearing a case imposes an obligation to remedy damage applying one of the grounds (art. 46 of the Criminal Code, $67 \S 3$ of the Criminal Code, $72 \S 2$ of the Criminal Code); second, the convict fails to fulfil this obligation; third, at the stage of enforcement proceedings, the penitentiary court in connection with early release on licence once again decides by way of an order on the obligation to remedy damage as a probationary condition (reference to art. $72 \S 2$ of the Criminal Code). Such multiplication of court decisions appears to be a misunderstanding. Thus, it seems that the solution adopted by the legislator should be applied to situations in which the trial court, for whatever reasons, did not impose an obligation to remedy damage and the penitentiary court has decided that the convict failed to redress the damage and the said obligation should be imposed on him. However, one might ask whether the penitentiary court will have enough evidence to arrive at a decision that the trial court did not reach. Serious objections could be raised with regard to the above-mentioned problem. Statistical data for the period of 2012 to 2017 regarding application of early release on licence do not allow for a conclusive determination of the number of judicial decisions concerning obligation to remedy damage issued pursuant to art. $159 \S 1$ of the Criminal Enforcement Code in conjunction with art. $72 \S 2$ of the Criminal Code, since these data refer to the execution of art. $72 \S 2$ of the Criminal Code in general. For this reason, it is impossible to reliably determine the number of such judicial decisions. It can be concluded however, given the above doubts, that the legislator has created an institution "on paper only", without previous, in-depth analysis of the compensatory model in criminal law.

\section{References}

Daszkiewicz W., Naprawienie szkody w prawie karnym, Warszawa 1972.

Gostyński Z., Karnoprawny obowiazek naprawienia szkody, Katowice 1984.

Gostyński Z., Obowiazek naprawienia szkody w nowym ustawodawstwie karnym, Kraków 1999.

Gostyński Z., "Zobowiązanie skazanego do naprawienia szkody jako orzeczenie co do roszczeń majątkowych", Palestra 1971, no. 5. 
Lachowski J., "Instytucja warunkowego przedterminowego zwolnienia", Państwo i Prawo 2008, no. 2.

Lachowski J., "Przesłanka materialna warunkowego przedterminowego zwolnienia na gruncie kodeksu karnego", Prokuratura i Prawo 2008, no. 11.

Lachowski J., "Warunkowe przedterminowe zwolnienie w prawie polskim na tle ustawodawstwa państw Rady Europy", [in:] X lat obowiązywania Kodeksu karnego wykonawczego, ed. S. Lelental, G.B. Szczygieł, Białystok 2009.

Lelental S., "Warunkowe przedterminowe zwolnienie w orzecznictwie Sądu Najwyższego i sądów apelacyjnych w latach 2000-II półrocze 2002 r.”, Przegląd Więziennictwa Polskiego 2003, no. 40-41.

Lelental S., "Warunkowe przedterminowe zwolnienie w orzecznictwie Sądu Najwyższego i sądów apelacyjnych w latach 2003-2004”, Przegląd Więziennictwa Polskiego 2005, no. 49.

Lelental S., "Warunkowe przedterminowe zwolnienie w orzecznictwie Sądu Najwyższego i sądów apelacyjnych w 2005 roku”, Przegląd Więziennictwa Polskiego 2006, no. 50.

Leonieni M., "Naprawienie szkody przy warunkowym zawieszeniu wykonania kary na tle nowej kodyfikacji karnej”, Palestra 1970, no. 5.

Leonieni M., "Wynagrodzenie szkody przy warunkowym zawieszeniu wykonania kary", Nowe Prawo 1963, no. 7-8.

Leonieni M., "Wynagrodzenie wyrządzonej szkody a warunkowe skazanie”, Nowe Prawo 1958 , no. 12.

Murzynowski A., "Nałożenie obowiązku naprawienia skutków przestępstwa jako element nowej polityki karania", Państwo i Prawo 1970, no. 5.

Stańdo-Kawecka B., "Warunkowe przedterminowe zwolnienie w krajach europejskich", Przegląd Więziennictwa Polskiego 2007/54.

Śliwowski J., "Filozoficzno-prawne znaczenie art. 62 polskiego kodeksu karnego", $P a$ lestra 1934, no. 7.

\section{Summary}

The author presents doubts concerning interpretation of numerous legal grounds for remedying damage caused by an offence in the field of criminal law, including imposition of an obligation to remedy damage in connection with early release on licence. Emphasis is placed on problems with their application in judicial practice. The author in principle views the amendments in the scope of compensatory measures as positive, however, she considers the possibility of further amendments, which would lead to more rational legislative solutions.

Keywords: remedying damage, compensation, release on licence, compensatory measure, offender, aggrieved party. 